\title{
A CAPTURA DO TEMPO NA ESCRITA BABILÔNICA DE ANTÓNIO LOBO ANTUNES
}

\author{
THE CAPTURE OF TIME IN THE BABYLONIAN \\ WRITING BY ANTÓNIO LOBO ANTUNES
}

Tatiana Prevedello ${ }^{1}$

\section{RESUMO}

A concepção do romance Ontem não te vi em Babilónia, de António Lobo Antunes, ao subverter os modelos clássicos de narração, instaura, em seu projeto de escrita, o emprego de recursos como os múltiplos pontos de vista narrativo, que combinam e (re)ordenam o testemunho das personagens de forma contínua, impossibilitando que o leitor se ampare em uma única e acabada versão dos fatos. A elaboração do tempo ficcional, nessa perspectiva, embora seja organizada de forma linear, uma vez que o romance se estrutura em capítulos que correspondem a uma hora específica no transcorrer de uma indelével madrugada, operacionaliza, por meio da percepção das personagens e dos recurso mnemônicos que utilizam para (des)organizar as suas lembranças, a experiência da eternidade. A análise dos marcadores temporais que, em conformidade com Paul Ricoeur, estão aliados à construção de um tempo eterno e inapreensível, constitu o nosso objeto de estudo, o qual se volta para uma escrita que, com insistência, questiona a sua própria forma, limites e finalidades.

PALAVRAS-CHAVE: narrativa contemporânea; personagens; instabilidade temporal.

\section{ABSTRACT}

The conception of the novel Didn't see you in Babylon yesterday, by António Lobo Antunes, subverts the classic models of narration and employs the use of resources as the multiples of the narrative points of view, which combine and reorder the testimony of characters on a continuous basis, 
making it impossible for the reader to rely on a single finished version of the facts. The elaboration of fictional time, in this perspective, although it is organized in a linear form, since the novel is structured in chapters which correspond to a specific time in the course of na indelible dawn, is operationalized, through the perception of the characters and mnemonic resources that use to disorganize your memories, the experience of eternity. The analysis of the temporal markers which, according to Ricoeur, are allied to the construction of an eternal and imperceptible time, constitutes our object of study, which turns to a writing that, with insistence, questions its own form, limits and purposes.

KEYWORDS: contemporary narrative; characters; temporal instability.

\section{“... CHEGOU A ALTURA DE DIZER AS HORAS": OS RELÓGIOS E A REGÊNCIA DO TEMPO}

Babilônia representa, na dimensão do imaginário coletivo, um espaço instaurado pelo caos, destituído de regras e de qualquer compreensão. A acepção mítica de Babilônia, se buscarmos enquadrá-la como evolução do antigo hebraico - "לבב" (Babel) - sugere desentendimento, especificamente de línguas e enunciados, tal como mostra o bíblico episódio da Torre de Babel (BIBLÍA Sagrada, 1993, p. 21-22).

Na Babilônia "criada” por António Lobo Antunes, imersa no “império das trevas", as vozes das personagens estão articuladas como um jogo, cujos movimentos exploram a variação e a multiplicidade combinatória. Assim, não perdemos de vista o conto borgiano "La lotería en Babilonia", no qual o "eu" que enuncia o texto se revela uno e múltiplo, pois "como todos los hombres de Babilonia, he sido procónsul; como todos, esclavo; también he conocido la omnipotencia, el oprobio, las cárceles. (...) He conocido lo que ignoran los griegos: la incertidumbre" (BORGES, 2012, p. 67). Nesse país, a loteria configura a principal realidade e, ao exercer seu governo, determina os ganhos e perdas dos habitantes de Babilônia, representando a figura de um Deus onipotente. O narrador, no decorrer do conto, explica esse sistema complexo como se procurasse compreender as imbricações de seu funcionamento. Os babilônios se entregam, de forma vertiginosa, a um jogo no qual são intercaladas poucas possibilidades, adversas no cômputo de números favoráveis à difícil combinação das jogadas, e onde há infinitos sorteios, nos quais nenhuma decisão se apresenta como final, pois todas se ramificam em outras:

(...) los ignorantes suponen que infinitos sorteos requieren un tiempo infinito; en realidad basta que el tiempo sea infinitamente subdivisible (...). Esa infinitud condice de admirable manera con los sinuosos números del Azar y con el Arquetipo Celestial de la Lotería, que adoran los platónicos... (BORGES, 2012, p. 73). 
A respeito dessa misteriosa Companhia, cuja história está subordinada, ou "contaminada", às mais diversas versões ficcionais, o narrador considera que nenhum livro é publicado sem que se apresentem divergências entre cada um dos exemplares, pois há um juramento secreto, prestado pelos escribas, segundo o qual a ordem que rege a escrita se atém a normas como a omissão, a interpolação, a variação e, também, à prática da mentira indireta. Nesse funcionamento silencioso, o qual se compara à ação de um Deus, é articulada toda sorte de conjecturas a respeito da existência da Companhia, chegando-se, por fim, à constatação de que é indiferente "afirmar o negar la realidad de la tenebrosa corporación, porque Babilonia no es otra cosa que un infinito juego de azares" (BORGES, 2012, p. 75).

A hipótese sobre os mecanismos articuladores da loteria da Babilônia serve como diretriz para pensarmos nas técnicas narrativas que são acionadas no processo de construção temporal de Ontem não te vi em Babilónia, onde todas as afirmações acerca da experiência de tempo são passíveis de ser negadas, e os recursos elencados por Borges como possibilidade de gerência da onipotente Companhia - a omissão, a interpolação, a variação - também são trazidos à cena narrativa do romance para o qual nos voltamos. Todavia, se tal como está narrado em La lotería en Babilonia, as personagens de Ontem não te vi em Babilónia "conhecem" a incerteza sobre si mesmas e sobre os "outros" coadjuvantes do enredo, não podemos, de forma alguma, afirmar que a construção ficcional de Lobo Antunes se compara a um "infinito jogo de acasos".

Os relatos, que abrangem oito narradores, principiam à meia-noite e são interrompidos ao amanhecer, ocasião em que a escrita da obra se encerra. A exemplo dos demais livros de Lobo Antunes, a execução arquitetônica de Ontem não te vi em Babilónia segue uma normatização delimitada e a estrutura gráfica demonstra contestar o aparente devaneio ilógico do texto. O emprego dessa técnica parece situar o livro no espaço da literatura projetada, que se atém a um plano formal bem estruturado e a uma metodologia precisa. O texto é constituído por seis partes maiores, que são designadas pela hora noturna, "meia-noite", e pelas diurnas, entre "uma hora da manhã" e "cinco horas", e se divide em quatro capítulos, os quais expressam a solidão de cada personagem que divaga sozinha entre memórias e simulacros de reminiscências. A cada capítulo são apresentados relatos de três personagens, a saber: Ana Emília, mãe de uma adolescente de quinze anos que se suicidou por enforcamento no galho de uma macieira; Osvaldo, um ex-torturador da ditadura salazarista; e Alice, sua esposa; estes são repetidos em todas as partes e, a cada duas sessões, é alterada a ordem de elocução. No quarto capítulo de cada parte maior é apresentado o discurso de uma personagem que até então não havia se manifestado.

A "escrita babilônica" antuniana torna o tempo indistinto e as limitações cronológicas inexatas. "Meia-noite" é a demarcação estrutural e cronológica que abre a incursão ao breu de Ontem não te vi em Babilónia, narrativa que, numa perspectiva contrária ao que sugere a organização de 
seus capítulos, ordenados em uma sequência temporal linear, articula-se nos movimentos pendulares de múltiplos tempos vivenciados pelas personagens. Instaura-se um eterno circuito de anaforismos que, ao se repetirem, demonstram exilar os sujeitos insones em suas imprecisões memorialísticas, desencadeadas no transcurso das horas até o expirar do texto, que irá se amparar em outra convenção temporal, localizada no último capítulo do romance: "Cinco horas da manhã". A imagem de um fio de estendal, suspenso horizontalmente no galho de uma macieira a sustentar o corpo de uma adolescente suicida, de quinze anos, oscilante no ar tal qual um pêndulo, serve-nos como dispositivo organizador das principais reflexões que pretendemos desenvolver sobre o processo de negação da temporalidade convencional em um texto que pauta a sua fluência escrita no ritmo mecânico dos relógios.

Os marcadores temporais, em Ontem não te vi em Babilónia, são exaustivamente explorados com a finalidade de inscrever o tempo em duas perspectivas principais. Em um primeiro momento, os relógios, sobretudo, têm o propósito de fixar a sucessão das horas no espaço noturno de uma madrugada insone e, pelo viés das reminiscências das personagens, atingir, como define Santo Agostinho, o "presente das coisas passadas" e as expectativas, ainda que céticas e desprovidas de qualquer esperança, voltadas para o "presente das coisas futuras", limitadas à ocasião em que a narrativa alcançar a manhã. Num segundo momento, se o tempo se inscreve na sucessão das horas conformadas pela formatação narrativa, seu aspecto estável ou linear é, novamente, sempre colocado em questão e confrontado com a eternidade que subsiste na consciência das personagens.

As personagens de Ontem não te vi em Babilónia compartilham uma experiência temporal fictícia semelhante, à medida que, mesmo na impossibilidade de comunicação, admitem a sucessão das horas que, a partir da meia-noite, primeira demarcação cronológica inscrita no texto, seguem em direção ao expirar da narrativa que irá ocorrer às cinco horas da manhã. A imobilidade das personagens, presas em suas camas e incapazes de conciliarem o sono, cria uma verdadeira obsessão pela marcação das horas e pelos instrumentos de medida, sobretudo os relógios, além de outros sinais que indicam a sua passagem. O tempo de enunciação da narrativa se inscreve, igualmente, no presente dessa noite insone. A figuração do deus Chronos é incisiva em Ontem não te vi em Babilónia, pois as horas que se escoam em direção à manhã estão rigidamente marcadas pelos instrumentos que mensuram o tempo, ou pelos objetos que interagem com as personagens.

A voz desprovida de linearidade de Ana Emília abre a primeira parte do romance. Entrecruzam-se reminiscências que evocam episódios de seu passado, cenas vividas junto à filha, o cenário do suicídio testemunhado por elementos que se tornarão uma recorrência obsessiva: a corda presa ao galho da macieira e as ervas que cercavam a referida árvore - “(...) 
apetece-lhe um chazinho das ervas junto às quais a minha filha se enforcou aos quinze anos senhora" (ANTUNES, 2006, p. 17) -, além da boneca que a adolescente trazia consigo, presente de Osvaldo: "apetece-lhe assustar-se com a boneca no chão, a cara contra barriga nenhuma que não deixava de girar, uma altura não à meia-noite como hoje" (ANTUNES, 2006, p. 17). As reflexões de Ana Emília, portanto, principiam a narrativa, pautadas, desde o início, por elementos que instauram a dicotomia entre o "tempo da alma" e o "tempo do mundo", como podemos observar na sequência de fragmentos que seguem:

Chegava sempre antes da sineta quando ia buscar a minha filha e tirando a madrinha da aluna cega a cochichar cumprimentos em tom de desculpas sem que eu a entendesse

(...)

e como deixei de ter filha cessei de respirar, não só a porta e as janelas trancadas, compartimentos desertos, poeira, o edifício da escola afinal abandonado e velho, a madrinha da aluna cega aproximou-se carregando cheiros antigos e nisto que alívio a sineta

(...)

morreu há uma data de anos, passa da meia noite

(...)

-Ana Emília

a perguntar as horas, o que os doentes se inquietam com as horas, como os intrigam que estranho

-Que horas são?

isto de segundo a segundo, duvidam, insistem

-De certeza?

que raio significam as horas para eles, continuará a existir a escola, a árvore de que nunca se soube o nome e a madrinha a vigiar a sineta nos seus cochichos de desculpa

(...)

(...) no fundo de mim uma sineta de escola que não pára, não pára sem que criatura alguma lhe toque salvo o vento, aproximo-me e o badalo sozinho (...) (ANTUNES, 2006, p. 13-20)

A descrição da experiência temporal das personagens nessa narrativa, a principiar pelo exemplo advindo da consciência insone de Ana Emília, ocorre no presente e se vale das coordenadas temporais que se constroem à medida que as horas são anunciadas. A reminiscência do soar da sineta da escola onde estudava a menina suicida é o primeiro indicativo concernente à passagem do tempo que o texto anuncia, entendendo-se que essa indicação mnemônica parte de uma ocasião presente, a qual é definida, nesse fragmento, como "meia-noite". Se as horas são demarcadas "segundo a segundo" e questionadas sobre a sua extensão e significado, elas também ecoam pelo som da sineta, que se estende de um ponto do passado e é repetido de forma obstinada na mente da personagem, pois "não pára, não pára".

Paul Ricoeur nos lembra que o tempo não poderia ser percebido em si mesmo, pois na verdade o apreendemos com uma representação indireta, dada pelas operações imaginativas que se aplicam aos objetos loca- 
lizados no espaço. A figuração do tempo integra a sua forma indireta de se expressar pelas vias da imaginação, conforme o filósofo explica:

(...) a representação do tempo sempre vem acompanhada de uma determinação do tempo, ou seja, de um lapso de um tempo particular, determinação que nada acrescenta à pressuposição de um tempo infinito do qual todos os tempos são partes sucessivas: é na determinação de sucessões particulares que o caráter indireto da representação do tempo fica mais claro (RICOEUR, 2010, p. 83, t. 3).

Se o tempo é perceptível apenas pela relação entre o que persiste e o que se modifica, pode existir um discernimento entre o caráter dicotômico de um "tempo que não passa" onde "tudo passa”. A duração de um fenômeno pode ser compreendida como a quantidade de tempo no decorrer do qual um substrato que permanece e persiste sofre mudanças. No tempo que sucede sem se referir à permanência, o existir apenas surge e desaparece desprovido de quantidade. Para que o tempo não venha a ser reduzido a uma sequência de aparecimentos e desaparecimentos, é necessário que ele mesmo permaneça. Todavia, apenas é possível identificar essa característica contemplando o que persiste nos fenômenos e o que se determina como substância, ao se estabelecer uma relação entre o que perdura e o que se modifica. Esse mecanismo, próprio da configuração temporal cronológica, é capaz de propiciar entre narrador e leitor a partilha de diversas modalidades de experiências temporais, que permitem a refiguração da leitura no próprio tempo.

Um exemplo emblemático na literatura moderna ocidental de criação de uma fábula sobre o tempo ocorre no romance de Virginia Woolf, Mrs. Dalloway. A expressão do tempo cronológico, nesse texto, é representada na ficção com bastante sonoridade pelo soar dos relógios, sobretudo, do Big Ben, que marca as horas. Todavia, como alerta Ricouer, "o importante não é esse alerta da hora, soando ao mesmo tempo para todos, mas a relação que os diversos protagonistas estabelecem com as marcas do tempo" (RICOEUR, 2010, p. 182, t. 2). A qualidade variável dessa relação, que ocorre conforme as personagens e as ocasiões com as quais interagem, forma a experiência temporal fictícia que a narrativa elabora com muita acuidade com o propósito de convencer o leitor. Os jogos que se articulam entre o "tempo dos relógios, tempo da história monumental, tempo das figuras de Autoridade: mesmo tempo!” (RICOEUR, 2010, p. 185, t. 2), exercem-se de forma muito mais complexa que a simples sinalização cronológica das horas descritas em todo o percurso narrativo do romance de Woolf:

- Está na hora - disse Rezia.

A palavra "hora" rebentou sua casca; derramou seus tesouros sobre ele; e seus lábios tombaram, como escamas, como limalhos, sem que ele nada fizesse para isso, duras brancas, imortais palavras, que voaram, colocando-se por si mesmas 
no seu devido lugar em uma ode ao Tempo; uma imortal ode ao Tempo (WOOLF, 1980, p. 69).

$(\ldots)$

(...) Mas eis que outro relógio, o relógio que sempre batia dois minutos depois do Big Ben, entrou com suas mangas cheias de bagatelas, que despejou no chão, como se ao Big Ben, tão solene, tão injusto, coubesse ditar a lei, com a sua majestade, ao passo que ele devia lembrar toda a espécie de coisas insignificantes (...) toda a espécie de pequeninas coisas, que inundaram a sala, saltando e dançando, ao despertarem com aquela solene pancada que batia em cheio, como uma barra de ouro no mar (WOOLF, 1980, p. 124).

No momento em que discorre a respeito do processo de "neutralização do tempo histórico", Ricouer (2010, p. 215, t. 3) observa, de forma muito perspicaz, que "personagens irreais (...) têm uma experiência irreal de tempo" (RICOEUR, 2010, p. 215, t. 3). Esse aspecto do irreal, para o filósofo, quer dizer que os registros temporais dessa experiência não apresentam como exigência uma ligação somente ao mecanismo espaçotemporal, que constitui o tempo cronológico. Por essa razão, tempo real e cronológico não precisam estar conectados um ao outro, tal como "mapas geográficos justapostos" RICOEUR, 2010, p. 215, t. 3), uma vez que a experiência temporal de um herói não necessita estar referida ao único sistema de datação e ao único quadro de todas as datas possíveis, o calendário, que é o ponto basilar universal para esse tipo de referência. Conforme Ricoeur, "da epopéia ao romance, passando pela tragédia e pela comédia antiga e moderna, o tempo da narrativa de ficção está livre das imposições que exigem transferi-lo para o tempo do universo" (RICOEUR, 2010 , p. 215 , t. 3$)$.

Para Ricouer, cada experiência temporal fictícia constrói o seu "mundo" e, cada um desses "mundos" se reveste de singularidades que o tornam incomparável em relação aos demais. Não apenas as intrigas, mas os "mundos" de experiências que elas constroem não são, tal como os segmentos do tempo sucessivo e único defendido por Kant, conforme refere Ricoeur, barreiras de um mundo imaginário único, pois as experiências temporais no âmbito da ficção não podem ser totalizadas.

Nos elementos que já referimos acerca da organização cronológica de Ontem não te vi em Babilónia podemos identificar, com bastante clareza, o processo em que, segundo Ricoeur, "as três relações dinâmicas de inerência, de consequência e de composição, ao organizarem as aparências no tempo, determinam, por implicação, três relações de ordem do tempo que definem a duração como grandeza de existência, a regularidade na sucessão e a simultaneidade de existência” (RICOEUR, 2010, p. 88, t. 3). Os aspectos qualitativos que marcam a experiência temporal fictícia desse romance, no que tange a sua duração, são conformados por sua formatação gráfica, na divisão dos capítulos que se estendem da meia-noite às 
cinco horas da manhã. A regularidade na sequência, por sua vez, é construída em consonância com o desenvolvimento dos capítulos e através de sua subdivisão. Assim, se por um lado a memória tem poder de suspender o instante presente e acessar recônditas lembranças do passado, esse procedimento não impede que as horas sejam representadas no romance obedecendo a uma sucessão inalterável, uma vez que dentro desse processo de representação não existe estagnação ou retrocesso: na perspectiva do relógio o tempo sempre evolui. A concomitância de existências das personagens, incomunicáveis entre si, mas vítimas de uma mesma noite insone, expressa-se na forma como apreendem a sucessão das horas, através dos objetos que marcam o tempo ou pelas vias de sua percepção sensorial. Observemos agora, nesta seleção de fragmentos extraídas da quinta parte do livro, "Quatro horas da manhã", como diferentes personagens, situadas em capítulos específicos, mas envolvidas pela simultaneidade de uma mesma hora, exprimem a sua experiência temporal:

[Osvaldo]

não era nada do que escrevi até agora o que queria dizer enquanto tenho tempo e tenho pouco já, uma questão de minutos se a terra empenar no seu eixo e há ocasiões em que empena, fica a vibrar num ressalto, quatro da manhã santo Deus (ANTUNES, 2006, p. 316)

[Alice]

meu Deus não me apetece que chova e apetece-me que chova, quatro e tal da manhã, cinquenta e poucos anos, sou velha, o soalho parece cavar-se como se uma pessoa a calcar a barriga das tábuas, a minha avó por ali enervada de não enxergar a azinheira, mesmo depois de não se levantar da cama continuou a moer-me o bichinho do ouvido (ANTUNES, 2006, p. 338)

[Ana Emília]

e quatro da manhã por fim, não de daqui a uma semana ou de ontem, quatro da manhã de hoje e as primeiras varandas, o empregado aceitou um licor a perguntar a si mesmo, não a mim (ANTUNES, 2006, p. 371)

[Marido de Ana Emília]

este fim de noite às quatro da manhã em que o relógio cessa, acabam-se as horas, nem um minuto nos falta, uma vibração do soalho que vai parando, parando e terminada a vibração as rolinhas quase de loiça que não pedem, não chamam, pode ser que a minha filha

(mesmo que não minha filha e sei que não minha filha a minha filha)

-Pai

do quarto dela ou do galho da macieira mas arredia, séria, nunca tivemos tempo para estar um com o outro numa época em que os inimigos da Igreja e do Estado mais os seus jornais impressos ao contrário nos obrigavam a ensurdecer em Peni- 
che, o médico a experimentar pulsos onde trepidavam calhaus (ANTUNES, 2006, p. 384)

A narrativa de Ontem não te vi em Babilónia, construída a partir do presente da enunciação, apreende, dessa forma, a existência das personagens em um único tempo cronológico, embora não exista um confronto físico na madrugada em que são subjugadas pela insônia. A problemática que Ricoeur explora no embate entre as ideias de Aristóteles e Agostinho pode, aqui, ser visualizada com clareza, pois é possível distinguir nesse texto uma "sucessão de instantes quaisquer", conformados pelas horas que avançam - "a partir da meia-noite todos os ruídos cessam" (ANTUNES, 2006, p. 36); "(uma e dezasseis da manhã acho eu, uma e dezassete, uma e dezoito, que injustiça a do tempo)" (ANTUNES, 2006, p. 111); "(às duas da manhã silêncio e não Peniche, Lisboa ...)" (ANTUNES, 2006, p. 185); "três e quinze da manhã e estou viva (...)” (ANTUNES, 2006, p. 241); “(quatro da manhã Jesus Cristo)" (ANTUNES, 2006, p. 317); “cinco da manhã e dia” (ANTUNES, 2006, p. 414) - onde se instaura a relação entre um passado mais longínquo - "mergulhei até ao caroço de minha infância e regressei sem ela, houve os corvos, a muralha, os gansos do pântano que o meu pai não matava" (ANTUNES, 2006, p. 283) - e um futuro que não vai além da expectativa da conclusão do livro e da indiferença em se alcançar a manhã - “(...) não me preocupa que a manhã chegue ou não chegue (...)" (ANTUNES, 2006, p. 237) -, mas articulados pelo presente, que é o instante em que ocorre a enunciação do texto. O texto explora a sucessão temporal embasada na relação de "anterior-posterior", bem como a relação irreversível que há entre o "antes do presente", ou passado, e o "depois do presente", ou futuro.

Sabemos que, se o calendário é o objeto que faz a computação dos dias, o relógio é o responsável pelas horas e suas subdivisões, pois como observa Ricoeur: “o 'relógio' é a coisa maneável que permite agregar à datação exata a medida precisa. Além disso, com a medida, o tempo fica definitivamente público" (RICOEUR, 2010, p. 144. t. 3). Por essa razão, verificar as horas em relógios não estabelece nenhuma relação com o ato de "dizer agora”, ação enraizada no fenômeno de contar o tempo, pois a história da mensurabilidade temporal remete ao esquecimento pelo qual todas as interpretações passam pelo "tornar-presente". Ao final desse esquecimento, é possível identificar o próprio tempo como uma continuidade de "agoras" quaisquer e anônimos: "quatro da manhã escrevo eu mas de quando, de daqui a uma semana, de ontem, de que estação, de que ano, quatro da manhã para mim, para você, para o meu pai, para quem, quatro da manhã (...)" (ANTUNES, 2006, p. 370). Se, sob uma perspectiva, na organização temporal da narrativa os intervalos são mensurados pelos relógios e pela percepção das personagens que intuem o movimento das horas, por outro lado se torna perceptível que o "agora" do texto, o qual pode estar inscrito como "meia-noite" ou qualquer delimitação que equivale às horas representadas textualmente, é suspenso pela irrealidade. Embora controlado por marcadores temporais que, como o ponteiro em seu percurso, movimentam o tempo de um "agora" para outro, o tempo inexato evocado pela me- 
mória presentifica a ausência na atualização de imagens que se inscrevem como lembranças.

\section{"(E NÃO PONHO O VERBO NO PRESENTE PORQUE SE RESIGNOU HÁ SÉCULOS)": O FIM DAS HORAS NA NOITE ETERNA}

A experiência fictícia do tempo cria conexões entre a temporalidade vivida e o tempo compreendido como uma dimensão convencional e reguladora do mundo, pois é possível verificar que os mais diversos gêneros literários não hesitam em envolver personagens advindas das páginas da história, acontecimentos passíveis de serem datados ou datáveis, espaços geográficos conhecidos, com personagens, fatos e lugares fictícios. Todavia, os eventos datados ou datáveis não conduzem o tempo da ficção para a dimensão onde gravita o tempo histórico. Ao discorrer a respeito das variações "entre o tempo vivido e o tempo do mundo" (ANTUNES, 2006, p. 103), Ricoeur assegura que existe uma "falha" ocasionada pelo pensamento reflexivo entre o tempo fenomenológico e o tempo cósmico.

O narrador - ou as diversas personagens-narradoras de Ontem não te vi em Babilónia - é ficcional e todos os indícios que remetem a eventos reais são destituídos de seu papel de "representância" no território do passado histórico e se inscrevem na irrealidade de outros acontecimentos. Ana Emília, o seu amante, Osvaldo, e a esposa deste, Alice, sobretudo, unem-se em um memorialístico desencontro insone, circundados pela solidão intransponível a prostrá-los em inerte letargia diante das traições que se consumam, de abandonos que se legitimam e da invencibilidade da morte.

O processo de "presentificação da ausência", inscrito na forma como os devaneios noturnos das personagens-narradoras e do narrador-autor (ou narradores-autores) são representados no texto, mostra a cristalização da eternidade pela ruptura com o tempo convencional, de forma que os instrumentos que se encarregariam de firmar essa convenção tornam-se inoperantes: "Quando estou muitas horas acordada a sentir o tempo que não sei para onde vai no relógio elétrico" (ANTUNES, 2006, p. 83); “(o relógio parou, se me ajudassem, não importa quem, qualquer pessoa serve, a parar igualmente)" (ANTUNES, 2006, p. 105); “este fim de noite às quatro da manhã em que o relógio cessa, acabaram-se as horas, nem um minuto nos falta" (ANTUNES, 2006, p. 384). Embora a narrativa esteja cercada de elementos que ratificam o transcorrer das horas por meio de marcadores temporais que registram esse movimento, há um duelo invencível entre o tempo que flui nas horas que compõem a narrativa e o tempo infinito das reminiscências, cuja duração é impossível de ser delineada, tal qual o corpo da adolescente suicida, preso por um fio de estendal no galho da macieira que gira na narrativa durante horas sem fim.

A inércia dos corpos das personagens não impede que sua consciência acompanhe o transcorrer das horas e desenvolva importantes 
questionamentos acerca da temporalidade convencional. Três percepções apresentam um significativo destaque nas reflexões que permeiam a sensibilidade temporal das personagens: o passado, "um lugar tão movediço" (ANTUNES, 2006, p. 364), que se reefetua no presente; o desejo de destrutibilidade do tempo convencional; e a sensação de pertencer a uma dimensão atemporal, que se aproxima da eternidade.

No processo de reatualização das lembranças na madrugada insone, contam-se acontecimentos destemporalizados que, à medida que são refigurados pela narrativa, acabam por se fundirem e conformar um tempo de que é impossível determinar a proximidade ou a distância. O elemento mais perceptível, embora não seja exatamente o mais decisivo, localizado na oposição estabelecida entre tempo fictício e tempo histórico, está presente na liberação do narrador, o qual não pode ser confundido com o autor. Os conectores específicos da reinscrição do tempo vivido sobre o tempo cósmico, tal como nos mostram os fragmentos selecionados, firmam-se na sobreposição temporal e na indeterminação das datas:

estávamos na minha dúvida sobre que dia é hoje, terça-feira, sexta, vinte e um, cinco, dezanove e qual o mês, qual o ano uma vez que os anos antigos a sucederem também, e eu a correr atrás do meu pai em torno do busto do filólogo e a contar os dedos fixando a macieira que amuou comigo a ralhar-me

(...)

o relógio parado numa hora sem importância visto que tantos tempos ao mesmo tempo pai e tantos dias juntos, o vinte e um, o cinco, o dezanove, lugares movediços a alterarem-se aumentando de pessoas, de vozes, o meu pai uma pergunta que não ouvi (ANTUNES, 2006, p. 358-360)

A natureza ficcional das personagens apresenta uma experiência irreal de tempo. O irreal figura, aqui, no sentido de que as marcas temporais dessa experiência não estão vinculadas à única trama espaçotemporal que constitui o tempo cronológico. Por esse motivo, as mesmas não requerem vinculação umas com as outras, pois cada experiência temporal fictícia realiza o desdobramento de seu mundo, revestido pela singularidade que o torna incomparável. Não somente as intrigas, mas também o universo constituído pelas experiências que elas mostram, não subjazem às limitações de um único mundo imaginário, pois as vivências temporais fictícias não são revestidas por um invólucro totalizante.

A compreensão do tempo passado da narrativa como um "quase passado temporal" mostra que os eventos apresentados em um texto de ficção são acontecimentos vinculados a uma voz narrativa que supõe a existência de um autor e, por conseguinte, pode ser entendida como a máscara fictícia de um “autor real”. Existe a expressão de uma voz que, ao articular sua fala, considera que o evento narrado de fato aconteceu. $\mathrm{O}$ exercício da leitura confere autenticidade ao acordo tácito que há entre o autor e o leitor, 
ao supor que os fatos apresentados pela voz narrativa, ainda que possam estar inscritos no presente, são provenientes do passado dessa voz, tal como podemos observar nos fragmentos do discurso de Ana Emília a seguir:

e eu a ir-me embora esquecida conforme devia ir-me embora antes de entrarem na sala não importa qual deles, não faz diferença a esta hora

(que hora?)

há um mês

(e que mês de que ano, que lugar movediço do passado continuando a existir ao mesmo tempo que nós ...)

(...)

há um mês

(não sei que mês de que ano, refiro que há um mês e o que é um mês neste lugar movediço em que as sombras se confun$\operatorname{dem}(\ldots)$

(...)

(o passado movediço por um instante fixo, o empregado fixo, eu fixa, os patos fixos na cómoda e portanto fixos no tanque sem nenhum motor dentro, o meu pai fixo a correr, o riso da minha mãe fixo

- De que estás a rir mãe?

qual a idade do seu riso)

(...)

(que dia é hoje, ajudem-me)

por um instante fixo, o empregado fixo, eu fixo, que terça-feira, que sexta-feira de que mês, de que ano, o meu pai morto ou irá morrer um dia

(irá morrer um dia?)

o meu pai morto, fixo a correr, o riso da minha mãe fixo

(-De que está a rir-se mãe de que me estou a rir?

e qual a idade do seu riso, qual a idade do meu) (ANTUNES, 2006, p. 364-369)

A aparente contradição entre o "passado movediço" e o "instante fixo" mostram que além de um episódio transcorrido em outra época ser reefetuado no presente de forma contínua, o tempo que corresponde ao presente da narrativa é neutralizado para ceder espaço a esse fato consumado que, embora fixado na consciência da personagem sob o estatuto de algo que passou, a acompanha com a conotação de eternidade, o que resulta em imprecisão no ato de ler as horas ou situar as datas.

O desejo de se evadir do tempo e contestar a apreensão formal das horas, realçado pela ação destruidora investida contra um relógio, mostra o ato que o pai da personagem Osvaldo praticou como uma tentativa de libertar-se da condição imposta por este objeto regulador do tempo do mundo: “(...) uma ocasião o meu pai deu corda ao relógio e enterrou-o a seguir para que não existissem horas cá em cima, o tempo destinado às toupeiras, aos vermes e ao fogo que não nos alcançará nunca (...)" (ANTUNES, 2006, p. 406). Convém destacar que o tempo oficial, que engendra a 
consciência das personagens na noite insone e conforma as suas angústias e temores, não é apenas o tempo convencional dos relógios, mas todos os aspectos da existência regulados pelas suas conveniências normatizadoras. Subsiste a reivindicação de libertar-se do tempo formal, ainda que seja impossível desvencilhar-se do movimento incessante das horas, como o narrador indaga: "(o relógio enterrado continuará a trabalhar?)” (ANTUNES, 2006, p. 407).

A narrativa de Ontem não te vi em Babilónia todavia, ainda que constantemente esteja a invocar a "história monumental", para utilizar o termo de Ricoeur, nas referências que faz ao regime salazarista, às ações comunistas, ao trabalho secreto da PIDE, aos combates contra os "inimigos de Deus e do Estado", mostra o que se poderia denominar de "tempo monumental", ao qual pertencem as figuras de autoridade e poder que instituem o tempo vivo e do qual o tempo cronológico é apenas uma expressão eufônica, pois é reiteradamente colocado em descrédito, como mostra a sequência de fragmentos transcritos, em que subsiste em uma mente atormentada o desejo de romper com as convenções das horas, ao questionar o seu aspecto narratológico e ficcional:

(...) provavelmente continuarás vivo enquanto o relógio for trotando na terra embora sem ponteiros nem mostrador nem vidro, não é o relógio que trota, é o tempo que não precisa de mecanismos para nada sem ligar a manhãs nem a noites nem àquilo que, nem àquilo que somos (...) (ANTUNES, 2006, p. 408).

Não é apenas o contraponto simplista entre o tempo dos relógios e as contradições interiores das personagens que devem ocupar o cerne de nossas reflexões, mas sim a diversidade das relações que há entre a vivência temporal concreta, sobretudo de Ana Emília, Osvaldo e Alice, em oposição ao tempo monumental: "em madrugadas como esta julgo escutar o relógio com as suas molas empenadas a trotar, a trotar (...) pensava no relógio e no tempo invisível diferente do tempo daqui, cavei no quintal sem encontrar o mostrador e as agulhas (...)" (ANTUNES, 2006, p. 407). A diversidade a respeito do tema dessa relação mostra ao leitor as inúmeras possibilidades de composição temporal que o texto desenvolve, pois em um mesmo plano existencial a apreensão do tempo pode ser variável: "por aí a cercarem-me embora cinco da manhã/ (no relógio enterrado quantas horas meu Deus?)" (ANTUNES, 2006, p. 407).

A madrugada transcorre impulsionada para frente, movida pelo propósito, apresentado desde o início do texto, de se atingir a manhã, a expectativa máxima de futuro que reside na conclusão da obra. As personagens não se libertam da opressão do tempo que as envolve, independente de qualquer ação que possa ser investida com o objetivo de destruir as horas que soçobram ao enredar de sua infelicidade estática. Ana Emília, Osvaldo e Alice escavam profundos túneis em seu passado, período de vas- 
tos infortúnios em suas reminiscências, que vai sendo estruturado no eixo presente das horas que escoam, com as quais compartilham a sua imobilidade insone.

A mãe da adolescente suicida, "tacteando as ruínas do passado" (ANTUNES, 2006, p. 21), lugar que, independente do seu ponto de localização em relação ao presente, admite incontáveis vezes ser um "lugar tão movediço", é a primeira a acionar, à medida que o "agora" da narrativa vai se configurando, o ritmo das lembranças obsessivas. Para ela, o vínculo mais expressivo com o presente está na alusão frustrada e desprovida de qualquer esperança em relação à imagem que nutre sobre o "homem que a prometeu visitar e não a visita”. Em sua mente são reiteradas imagens que afirmam o estado claustrofóbico em que se encontra desde a morte da menina, pois "como deixei de ter filha cessei de respirar" (ANTUNES, 2006, p. 13), e atingem uma dimensão mais ampla ao revisitar o episódio em que a avó enterra, vivas, as crias de uma gata:

e o meu avô a desviar-se de nós com o osso da garganta para baixo e para cima enquanto a minha avó ia tapando as crias, alisava a terra com as botas e os gemidos cessavam, a gata por fim resignada na copa, à espera, horas no relógio da consola, quatro ou cinco, com mecanismos a obrigá-las a desempenharem-se que bem se percebia o esforço das molas conduzindo-as até à bordinha e deixando-as cair, no cair da última a minha avó esfregava as solas no capacho a olhar a gente num desafio ou assim

(e se calhar procurando moedas nos bolsos por trás do desafio)

à medida que a gata farejava a terra alisada, sumia-se nos feijoeiros e regressava dois dias depois a dobrar-se-lhe de desgosto nas pernas, se tivesse herdado o relógio que venderam com os tarecos ao venderem a casa confirmava que meia-noite, um relógio de medalhão de porcelana representando um coche, dois cavalos (ANTUNES, 2006, p. 20-21).

A representação desse relógio não herdado que impede Ana Emília de confirmar as horas deduzidas por intuição, no qual um coche conduz dois cavalos, um castanho e um pardo ou, como em seguida retifica "um castanho e um branco que a vida empardeceu" (ANTUNES, 2006, p. 21), também ilustra o processo de "fabricação das horas", em seu interior, por pesos e volantes, manipulados pelo "sujeito de chicote a segurar nas rédeas" (ANTUNES, 2006, p. 21) do tempo, "trazendo para cima esses pingos de som” (ANTUNES, 2006, p. 29). A alusão às crias da gata, enterradas vivas pela avó, oferece uma dimensão do estado da personagem que, ao ritmo das imagens que circulam obsessivamente - o corpo da filha suspenso no galho de macieira "na ponta da corda ou do fio de estendal que ia girando devagar" (ANTUNES, 2006, p. 29), as ervas que circundam a árvore, uma boneca, "(dúzias de borboletas)" (ANTUNES, 2006, p. 29) - oscila do presente em direção ao passado. Isso ocorre como se percorresse esse trajeto 
constituído por diversas camadas em movimentos descendentes onde, em cada círculo, predomina a sensação de asfixia que, no presente da narrativa, a impede de respirar e, no ponto mais remoto do passado resgatado em sua memória, a mantém soterrada junto às crias da gata. É no discurso de Ana Emília que aparece, pela primeira vez, uma clara alusão ao texto de $A$ divina comédia, ao expressar que o tempo, simultaneamente cronometrado e destituído de qualquer medida, mostra que a madrugada avança, mas que em suas angústias e temores as personagens sucumbem a uma eternidade dantesca: “(...) vozes de almas do Purgatório sofrendo na caldeira que implorava socorro” (ANTUNES, 2006, p. 23).

Assim, da constatação sobre o passado como um "lugar movediço" que se altera à simbólica destruição do tempo monumental figurada no relógio, igualmente enterrado, as personagens atingem, em vida, a atemporalidade eterna - "qualquer coisa de intemporal a serenar-me e o mundo lento, eu eterno" (ANTUNES, 2006, p. 413-414) que, ao contrário da proposta apresentada por Dante, nega o amparo do céu e investe, gradativamente, na representação de espaços opressivos como o Purgatório e o Limbo e, por conseguinte, o próprio Inferno: “(...) o céu a ocupar-se consigo mesmo, alheado, mas o que importa o céu que não se importa connosco, mencionem o Purgatório ou o Limbo e é provável que lhes dê atenção, agora o céu que me rala" (ANTUNES, 2006, p. 321). A personagem Alice, da mesma forma, transmite em seu discurso a sensação de desamparo divino ou, inclusive, a negação da entidade suprema, contra a qual profere injúrias, diante da constatação de que o naufrágio de sua existência assemelha-se à eternidade infernal:

chamo-me Alice meu Deus, não permitais que as chamas do Inferno, não consintais que eu arda, eu na cancela à espera, o homem com a voz de boneca solta na barriga ou um cachorro, devia ser um cachorro, seja um cachorro que se perdeu da matilha convocado por um instinto qualquer procurando-me, acabou-se o céu em Évora, há um espaço onde paus de fio, galhos e portanto não há céu e Deus não existe que sorte, se calhasse existir zangava-se comigo e as zangas de Deus estátuas de sal, gafanhoto (...)

$(\ldots)$

e aceito porque Deus não existe, o padre mentiu e a prova que não existe é o céu desabitado (...)

-Chamo-me Alice e vou consumir-me no Inferno (ANTUNES, 2006, p. 61).

A Bíblia hebraica é um dos mais contundentes exemplos de apreensão do tempo nas suas relações com a eternidade divina. O intertexto bíblico aludido desde o título do romance, invocado por Alice ao se referir ao episódio de Sodoma e Gomorra - "estátuas de sal" - e às pragas do Egito - "gafanhotos", amplia-se, sobretudo, na consciência da personagem Osvaldo que, em eloquente discurso, engloba em suas reminiscências os 
propósitos da ditadura salazarista e as suas ações de policial da PIDE. Observemos, no fragmento que segue, como a voz de Osvaldo urde, em sua agonia insone, convicções políticas às religiosas, em uma totalidade profundamente inquisidora:

(...) talvez as almas encontrassem no fundo de seus invólucros terrenos antecipando o Juízo que nos separará dos pecadores inimigos da Igreja e do Estado, sodomitas, gatunos, a orla da lagoa uma espuma tão negra como a que supomos no Inferno isto é a bílis dos sodomitas a arder de castigo, cujos fluídos orgânicos o Antigo Testamento condena (...)

$(\ldots)$

(escrevi quatro horas da manhã e falso, quatro horas e dezoito e o dezoito terrível, coloquem moedas verdadeiras na caixa das almas, não obriguem Deus a zangar-se (ANTUNES, 2006, p. 320-321).

A percepção temporal de Osvaldo exprime a agonia de uma alma para a qual o tempo monumental é insuportável; a relação que a morte pode ter com a eternidade, além disso, intensifica essa agonia, segundo as interpretações da relação entre eternidade e o tempo que são abordadas nas Confissões de Santo Agostinho:

(...) quem o poderá prender e fixar, para que pare um momento e arrebate um pouco do esplendor da eternidade perpetuamente imutável, para que veja como a eternidade é incomparável, se a confronta com o tempo, que nunca pára? Compreenderá então que a duração do tempo não será longa, se não se compuser de muitos movimentos passageiros. (...) Na eternidade, ao contrário, nada passa, tudo é presente, ao passo que o tempo nunca é todo presente. Quem poderá prender o coração do homem, para que pare e veja como a eternidade imóvel determina o futuro e o passado, não sendo ela nem passado nem futuro? (AGOSTINHO, 2004, p. 319-320)

É, portanto, a respeito dessa falha insuperável, aberta entre o tempo monumental e o tempo mortal da alma, que se distribuem e se ordenam as experiências temporais de cada uma das outras personagens e seu modo de negociar a relação entre as duas margens separadas.

O tempo enunciado pelas vozes narrativas de Ontem não te vi em Babilónia, que uma das personagens se recusa a situar no "presente" por ter "se resignado há séculos", mostra a diversidade de perspectivas temporais que, cooexistentes no espaço do livro, são articuladas em um mesmo fluxo narrativo, independente da personagem a qual, a cada capítulo, tem o seu discurso a comandar o texto. Nesse fluxo textual, como sabemos, o tempo monumental é balizado na marcação das horas que seguem, de forma ininterrupta. Todavia, além da perspectiva presente para onde a consciência das personagens se dirige - a manhã que despontará e, com ela, o fim do livro -, dos movimentos circulares operados em direção ao "passado movediço" 
a alterar-se cada vez que é revisitado, das sucessivas indagações que são tecidas a respeito da credibilidade do tempo apreendido pelos relógios e as investidas contra a destruição dos intrumentos de mensuração das horas, prevalece a sensação angustiante de que esta noite pertence à eternidade em sua mais dilacerante expectativa infernal, conforme relata Osvaldo:

ão tenho muito mais a acrescentar a não ser que vos odeio a todos: desejo do fundo do coração que a vossa alma se consuma no Inferno pelos séculos dos séculos até que o espírito de Deus torne a mover-se sobre as águas e me deixem em paz (...)

$(\ldots)$

(...) não tenho muito mais a acrescentar a não ser que enquanto ardem no Inferno pelos séculos dos séculos, até que o espírito de Deus torne a mover-se sobre as águas a perguntar por nós Suas criaturas e Seus filhos

$(\ldots)$

(...) como eu desejando-lhe o Inferno pelos séculos dos séculos, estalos de dor, torresmos, torresmos (...) (ANTUNES, 2006, p. 399-402).

O discurso de Ontem não te vi em Babilónia é configurado pelo pensamento das personagens, cuja consciência segue em fluxo contínuo e constitui uma experiência temporal engendrada pela escrita que explora os limites da refiguração no tempo pela narrativa na perspectiva da eternidade. O enredo é rico na exemplificação de como o plano fictício tem o poder de multiplicar as experiências de eternidade, a considerar que cada obra de ficção cria o seu próprio "mundo" temporal e é sempre nesse universo possível que o tempo permite ser ultrapassado pela eternidade e a ficção possibilita experimentos em número ilimitado.

Todos os tempos do passado, independente de terem sido vividos, imaginados, inventados ou alterados pelo estado de letargia das vozes que (des)coordenam a organização da narrativa, têm sua imagem fantasmagórica incisivamente reiterada no presente. Nesse contexto, as alusões ao tempo nunca feliz da infância mesclam-se aos traumas e angústias que se imprimiram nos mais diversos momentos da vida adulta e jamais deixam de rondar as horas insones que configuram o "presente das coisas presentes": "(o que é a infância da gente, não nos deixa, acompanha-nos)" (ANTUNES, 2006, p. 416).

O tempo eterno e inapreensível da rememoração confronta-se com a sucessão cronológica das horas, que aprisiona os narradores na consciência de suas múltiplas limitações e impossibilidades. A reiteração de enunciados idênticos que se imprimem nas "falas silenciosas" das personagens e que são continuamente repetidos pelos mesmos sujeitos em diversas 
ocasiões da narrativa, compondo uma modalidade de variação sobre uma mesma temática, exprimem-se e cristalizam-se por meio da lembrança dos eventos mais significativos (in)experimentados pelas personagens insones até que o tempo do romance, que "pode ler-se no escuro" (ANTUNES, 2006, p. 479), chegue ao fim.

\section{REFERÊNCIAS BIBLIOGRÁFICAS}

AGOSTINHO. Confissões. Trad. J. Oliveira Santos; A. Ambrósio de Pina. São Paulo: Nova Cultural, 2004.

ANTUNES. Ontem não te vi em Babilónia. Lisboa: Dom Quixote, 2006.

BÍBLIA. Português. Bíblia Sagrada. Lisboa: Paulus, 1993.

BORGES, Jorge Luis. Ficciones. Buenos Aires: Sudamericana, 2012.

CAMMAERT, Felipe. O relógio avariado: sobre algumas representações do "tempo da memória" na obra de António Lobo Antunes e na arte contemporânea". In: ALVES, Fernanda Mota; TAVARES, Sofia et al. Filologia, memória e esquecimento. Act. 20: alteridades, cruzamentos, transferências. Lisboa: Húmus, 2010. p. 244-256.

RICOEUR, Paul. Tempo e narrativa: a intriga e a narrativa histórica. Trad. Claudia Berliner. São Paulo: Martins Fontes, 2010. t. 1.

- Tempo e narrativa: a configuração do tempo na narrativa de ficção. Trad. Márcia Valéria Martinez de Aguiar. São Paulo: Martins Fontes, 2010. t. 2.

Tempo e narrativa: o tempo narrado. Trad. Claudia Berliner. São Paulo: Martins Fontes, 2010. t. 3.

SEIXO, Maria Alzira (coord.). Dicionário da obra de António Lobo Antunes. Lisboa: Imprensa Nacional - Casa da Moeda, 2008, 2v.

WOOLF, Virginia. Mrs. Dalloway. Trad. Mario Quintana. Rio de Janeiro: Nova Fronteira, 1980.

Recebido para publicação em 21/01/2017

Aprovado em 13/06/2017

\section{NOTAS}

1 Doutora em Estudos de Literatura: Literatura Portuguesa e Luso-Africanas, pela Universidade Federal do Rio Grande do Sul - UFRGS. Professora do Instituto Federal Farroupilha - IFFar. E-mail: t_prevedello@hotmail.com 